\title{
牛精液の細菌污染防止に関する研究
}

\section{I. 原精液の細菌污染の実態調查}

\author{
橋本 和 典
}

（農林省家畜衛生試験場 中国支場）

精液の細菌污染を防除することは, 精液の保存の上か らも, 人工授精に供用した場合の雌性生殖器への感染防 止，また受胎率の向上のためにも重要である。1939 年

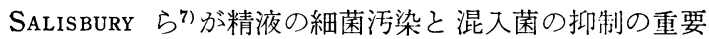
性について，この分野の研究者の注意をひいてから，精 液内に混在する細菌の種類および数, 細菌混入精液の受 胎に及ぼす影響，あるいは混入細菌の抑制剂とその効果 などについて多くの研究者により報皆されている。

わが国においては西川ら4)の研究によって, sulfa 剂 を加えた精液希釈液が創製され，さらに混入細菌の抑制 剂として penicillin (PC), dihydrostreptomycin (SM) の合剂が添加され，人工授精に広く応用されて優れた効 果を収めている。

最近の人工授精には, 受胎率の问上をはかるため, 子 婜内深部注入法が行なわれており，精液の細菌浰染の防 止ないし混入細菌の抑制ということは, 細菌性製殖障害 を防ぐ意味からきわめて重姴な問題と考えられる。

著者は，このような観点から牛精液の細菌污染防止に つき若干の検討を行なってきたが，その第 1 報として, 牛原精液の細菌污染の笞について報告する。

\section{検查材料および方法}

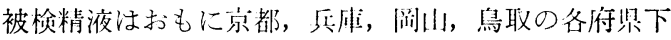
で繁殖に供用中の乳牛および和牛の程雄牛からえられた 延 221 例である。精液は人工塏により採取ののち，た だもにその $0.1 \sim 0.5 \mathrm{~m} l$ を滅菌小試験管にとり, 約 $4^{\circ} \mathrm{C}$ に保たながら研究宝に輸送し細菌検査に供した。精液の

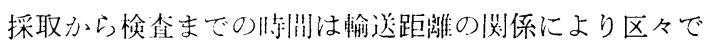

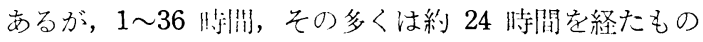
だあった。

Studies on the prevention of bacterial contamination of bull semen. I. Bacterial contamination of original semen and effects of preputial douche.

Hashimoto Kazunori (Chugoku Branch, National Institute of Animal Health, Wadayama, Hyogo) Jap. J. Animal Reprod. 12 (3), 1966.
混入細菌数の測定：原精液を生理食塩水で $10^{-3}$ $10^{-6}$ まで希䣋し，各希䣋段階を 2 枚ずつ牛血清加寒天 平板に混釈培養を行ない, $37^{\circ} \mathrm{C} て ゙ ~ 48$ 時間培養して, そ の発育集落数の平均から, 原精液 $1 \mathrm{ml}$ あたりの混入生 菌数を求めた。

細菌叢の検査：10 倍に希釈した原精液を 1 滴あて $5 \%$ 牛血液加寒天およびサブロー寒天の平板培地に滴下 し,コンラージ棒で各培地に 2 枚ずつ速統塗抹した。血 液加寒天は $37^{\circ} \mathrm{C} 48$ 時間, サブロー寒天は $30^{\circ} \mathrm{C} 72$ 時 間培養し，グラム陽性菌については BERGEY's Determinative Bacteriology (7 版，1957）により，またグラム 陰性菌は坂崎, 波岡共著「腸内細菌検菜法」により, そ れぞれ発污した細菌の同定を行なった。なす同定が困難 であった菌種は，末同定のグラム陽性菌，陰性菌とし て，それぞれ一括した。

\section{検查成績}

混入細菌数：原精液の細菌污染度は一般にいちじる しく高く，その混入菌数は区ヶであって $10^{3} \sim 10^{7} \beth / \mathrm{m} l$ にわたって挹，最低は $2,000 コ / \mathrm{ml}$, 最高は $1.7 \times 10^{7}$

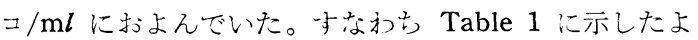
うに, 221 例のうら $10^{4}=/ \mathrm{m} l$ 以下はわずふ $4.1 \%$ に 导ぎず, $10 \times 10^{4}=/ \mathrm{m} l$ 以下が $26.3 \%, 30 \times 10^{4} \sqsupset / \mathrm{m} l$ 以下のものが $53.9 \%$ で，全体の約 8 割の $78.3 \%$ の精 液では混入菌数が $100 \times 10^{4}=/ \mathrm{ml}$ 以内であった。しか し $100 \times 10^{4}=/ \mathrm{m} l$ を越えるものが $21.7 \%$ の例に涩め られ, さらに混入菌数が $1,000 \times 10^{4}=/ \mathrm{ml}$ 以上のもの が $0.9 \%$ にみられた。

これらを授精前に创支腔洗浄を実施した群（68 例）と 実施していない群 (153 例) とに区分すると, 混入菌数 が $10 \times 10^{4}$ ב $/ \mathrm{ml}$ 以下のもの洗沵群では $45.6 \%$, 無 洗浄群では $17.8 \%$ となり, $100 \times 10^{4} \mathrm{~J} / \mathrm{ml}$ 以上は前者 では $7.3 \%$, 後者では $28.3 \%$ であって, 洗浄群の混入 菌数は非洗浄群に比べて少なくなっている傾向が認めら れた。 
Table 1. Number of bacteria recovered from original bull semen

\begin{tabular}{c|c|c|c}
\hline \hline \multirow{2}{*}{$\begin{array}{c}\text { Number of } \\
\text { isolated } \\
\text { bacteria }\end{array}$} & \multicolumn{2}{|c|}{ Number of semen samples (\%) } \\
\cline { 2 - 4 } $10^{4} / \mathrm{m} l$ & Preputial douche before & semen collection & Total \\
\cline { 2 - 4 }$<$ & + & - & \\
\hline 1.0 & $9(13.2)$ & 0 & $9(4.1)$ \\
$1.1 \sim 10.0$ & $22(32.4)$ & $27(17.8)$ & $49(22.2)$ \\
$10.1 \sim 20.0$ & $11(16.2)$ & $24(15.8)$ & $35(15.8)$ \\
$20.1 \sim 30.0$ & $10(14.7)$ & $16(10.4)$ & $26(11.8)$ \\
$30.1 \sim 40.0$ & $5(7.4)$ & $7(4.6)$ & $12(5.4)$ \\
$40.1 \sim 50.0$ & $1(1.5)$ & $12(7.9)$ & $13(5.9)$ \\
$50.1 \sim 60.0$ & $2(2.9)$ & $6(3.9)$ & $8(3.6)$ \\
$60.1 \sim 70.0$ & $1(1.5)$ & $7(4.6)$ & $8(3.6)$ \\
$70.1 \sim 80.0$ & $1(1.5)$ & $5(3.3)$ & $6(2.7)$ \\
$80.1 \sim 90.0$ & $1(1.5)$ & $4(2.6)$ & $5(2.3)$ \\
$90.1 \sim 100.0$ & 0 & $2(1.3)$ & $2(1.3)$ \\
$100.1 \sim 200.0$ & $2(2.9)$ & $21(12.5)$ & $21(9.5)$ \\
$200.1<$ & $3(4.4)$ & $24(15.8)$ & $27(12.2)$ \\
\hline Total & 68 & 153 & 221 \\
\hline & & & \\
\hline
\end{tabular}

また菌数を対数変換して両群の混入菌数を比較する と, Fig. 1 にみられるように，無洗浄群における出現 頻度の分布はほぼ正規型を示しており，その平均值は 5,602 (実数 $39.9 \times 10^{4} \beth / \mathrm{ml}$ ) であった。洗浄群の菌数 の分布は不規則であるが, 出現頻度は無洗浄群に比して かなり低位に偏より, その平均值は 4,979 (実数 $9.5 \times$ $\left.10^{4} コ / \mathrm{m} l\right)$ であった。これらの点から, 両群間の細菌 污染の状況はあきらかに異なり，包皮腔の洗浄により原 精液への混入菌数はいちじるしく減少することが認めら れた。

なお, 洗浄群の混入菌数の分布が正規型を示さなかっ たことは，洗浄の方法が場所により異なり，様々な方法 で行なわれていることに起因すると思われ，衛生的に十 分な洗浄が実施されている某人工授精センターでの採取 精液では, 混入菌数が $10 \times 10^{4}=/ \mathrm{m} l$ を越えるものが少 なかった事実はそれを裏付けるものであろう。

つぎに包皮腔洗浄の効果を実験的に確認するため, 場 内繫養の雄牛について, 包皮腔洗浄と洗浄後の採取精液 間の混入細菌数の比較を行なった。まず第 1 回目は包 皮腔洗浄をしないで精液を採取し, 約 1 時間後に包皮 腔を洗浄してから第 2 回目の採精をした。洗浄には滅 菌生理食塩液を用い, 1 回あたり約 $200 〜 300 \mathrm{ml}$ を洗浄 嘴管で包皮腔内に注入し，包皮口を閉じて十分にマッサ ージしながら洗浄し，これを 3 回反覆した。なお包皮

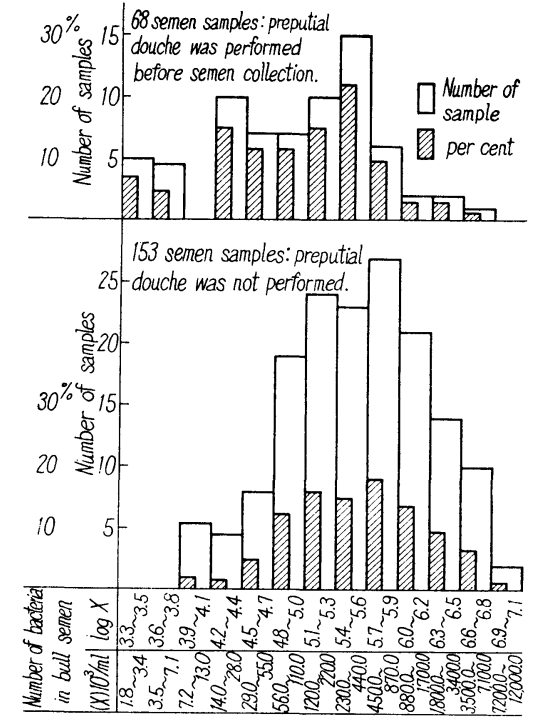

Fig. 1. Distribution of number of bacteria by logalithmic change

Table 2. Comparison of number of bacteria from bull semen collected before and after preputial douche

\begin{tabular}{c|r|r|r}
\hline \multirow{3}{*}{ Bull } & \multicolumn{2}{|c|}{$\begin{array}{c}\text { Number of bacteria } \\
\text { from bull semen }\left(10^{4} / \mathrm{m} l\right)\end{array}$} & $\begin{array}{c}\text { Rate of } \\
\text { Recreased } \\
\end{array}$ \\
\cline { 2 - 4 } & \multicolumn{2}{|c|}{ Preputial douche* } & $\begin{array}{c}\text { After } \\
\text { (Mean) }\end{array}$ \\
\cline { 2 - 4 } F-1 & 97.5 & 1.1 & $1 / 88.5$ \\
B-1 & 614.5 & 52.9 & $1 / 11.6$ \\
F-2 & 30.3 & 2.9 & $1 / 10.4$ \\
B-2 & 524.5 & 15.3 & $1 / 34.2$ \\
F-3 & 124.5 & 11.8 & $1 / 10.6$ \\
B-3 & 48.7 & 3.3 & $1 / 14.8$ \\
& & & $(1 / 28.3)$ \\
\hline
\end{tabular}

Control; Preputial douche was not perfromed

\begin{tabular}{c|r|r|r}
\hline & $\begin{array}{c}1 \text { st } \\
\text { collection }\end{array}$ & $\begin{array}{c}2 \text { nd } \\
\text { collection }\end{array}$ & \\
\hline A & 271.4 & 78.3 & $1 / 3.5$ \\
B & 54.5 & 33.0 & $1 / 1.7$ \\
C & 67.0 & 28.4 & $1 / 2.2$ \\
D & 91.2 & 50.5 & $1 / 1.8$ \\
E & 40.8 & 18.2 & $1 / 2.2$ \\
F & 118.0 & 38.0 & $1 / 3.1$ \\
& & & $(1 / 2.4)$ \\
\hline
\end{tabular}

* Preputial douche with $200 \sim 300 \mathrm{~m} l$ of sterilized saline was performed 3 times successively. 
腔洗浄をしなくても連続採取による 2 回目精液への混 入菌数が減少する可能性学考慮して，べつに包皮腔を洗 浄しないで 30 分間隔で採精し，この場合の混入菌数の 状態をしらべこれを対照とした。

その結果, Table 2 に示したように, 洗浄後の採取精 液では洗浄前のそれに比べて $1 / 10.4 \sim 1 / 88.5$, 平均 $1 /$ 28.3 といちじるしく減少した。また洗浄しないで連続 採取した場合も，2 回目の精液では 1 回目に比べて 1/ $1.7 \sim 1 / 3.5$, 平均 $1 / 2.4$ に減少したが，その減少率は 洗浄群より明らかに低かった。

これらの結果から，原精液への細菌污染原としては包 皮腔内付着細菌が大きな役割を演じており，十分な包皮 腔洗浄は精液の細菌污染を防止するためにきわめて有効 であることが，実態調査のうえからも実験的にも確認す ることができた。

検出菌種：219 例の原精液から分離した菌株数は 750 株であって, Table 3 に示したように，検出菌種は

Table 3. Species of microorganisms from 219 bull semen samples

\begin{tabular}{|c|c|c|c|}
\hline $\begin{array}{l}\text { Species of } \\
\text { organism }\end{array}$ & \multicolumn{2}{|c|}{$\begin{array}{l}\text { Number of } \\
\text { strains } \\
\text { recovered } \\
\%\end{array}$} & $\begin{array}{l}\text { Recovery } \\
\text { of per } \\
\text { semen } \\
\text { sample \% }\end{array}$ \\
\hline Micrococcus & 145 & 19.3 & 66.3 \\
\hline Diphtheroid & 90 & 12.0 & 41.1 \\
\hline Staphylococcus & 65 & 8.7 & 29.7 \\
\hline $\begin{array}{l}\text { unidetified } \\
\text { Gram positive } \\
\text { rods, non-spore }\end{array}$ & 59 & 7.9 & 27.0 \\
\hline Alcaligenes & 45 & 6.0 & 20.5 \\
\hline Eschrichia coli & 42 & 5.6 & 19.4 \\
\hline Bacillus & 42 & 5.6 & 19.4 \\
\hline Streptococcus & 40 & 5.3 & 18.3 \\
\hline Achromobacter & 36 & 4.8 & 16.4 \\
\hline Proteus & 31 & 4.5 & 15.5 \\
\hline Yeasts & 31 & 4.1 & 14.3 \\
\hline Gaffkya & 23 & 3.1 & 10.5 \\
\hline Providencia & 23 & 3.1 & 10.5 \\
\hline Corynebact. renalis & 19 & 2.5 & 8.5 \\
\hline Pseudomonas & 16 & 2.1 & 7.3 \\
\hline Chromobacterium & 15 & 2.0 & 6.9 \\
\hline $\begin{array}{l}\text { unidentified Gram } \\
\text { negative rods }\end{array}$ & 10 & 1.3 & 4.6 \\
\hline Klebsiella & 7 & 0.9 & 3.2 \\
\hline Saricina & 4 & 0.5 & 1.8 \\
\hline Hemophilus & 4 & 0.5 & 1.8 \\
\hline Total & 750 & & \\
\hline
\end{tabular}

きわめて多岐にわたっていた。これらのほかに数種の糸 状徽類（Mold）も発育した例もあったが，それらはこ の集計から除外した。分離菌株は 20 種（属）に分類さ れ，そのうち，もっとも多く検出されたのは Micrococcus で 145 株, 19.3\% をしめ, その検出頻度は $66.3 \%$ であった。それについで Diphtheroid が 90 株，12.0\% でその検出頻度は $41.1 \%$ あった。以下扮もなものを順 挙すると, Staphylococcus 8.7\% (検出頻度は 29.7\%), 末同定 グラム陽性桿菌 $7.7 \%$ (27.0\%), Alcaligenes $6.0 \%(20.5 \%)$, Escherichia $5.6 \%(19.4 \%)$, Bacillus $5.6 \%(19.4 \%)$, Streptococcus $5.3 \%$ (18.3\%), Achromobacter $4.8 \%$ (16.4\%), Proteus $4.5 \%$ (15.3\%), Yeast $4.1 \%(14.3 \%)$ となっていた。

また個々の原精液の検出菌種類は，3種（属）検出さ れたものが 219 例中 79 例 $(39.1 \%)$ ともっとも多く, ついで 4 種, 5 種, 2 種, 6 種, 1 種, 7 種の順であ った。

なお前述の包支腔洗浄試験を行なった際の洗浄排出液 の含有の菌類は $10^{6} \sim 10^{9}=/ \mathrm{m} l$ であり, その検出菌種 は原精液のそれとほぼ同様な傾向が認められた。

\section{考察}

牛の原精液から検出された細菌の種類忹，研究者によ り，精液採取法により，また種雄牛の飼養管理状態によ りさまざまであるが,ブルセラ病，ビブリオ病など特異的 な感染症のような場合を除き，外見上健康な種雄牛の精 液からは, 通常 Micrococcus, Staphylococcus, Streptococcus, Diplococcus, Escherichia, Proteus, Pseudomonas, Alcaligenes, Bacillus, Diphtheroid など種々の細 菌が検出されている。

精液内混入細菌の有害性について, WiLliAM ら び GILMAN ${ }^{2)}$ は授精能力の低下している種雄牛の精液に は，正常種雄牛のそ征比べて多数の混入細菌が認めら 秃たこと定報告して京り，WEBSTER ${ }^{12)}$ は授精成績の不良 な種雄牛の精液中に多数の溶血性レンサ球菌を検出し,

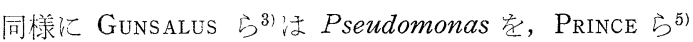
はグラム陽性双球菌なよでグラム㓌性桿菌が多かったこ とをそれぞれ報告している。

また細菌の精子生存性に交よぼす影響について，EDOー MONDSON ら 性菌種によりことなり，溶血性を有する細 菌は精子の生存に有害に㗢くが， ある種の非溶血性細菌 はその代謝過程で精子の生存に好影響を子よぼすこと在 述べている。TRUBLOOD ${ }^{11}$ 法精液に種々の細蔆定加え, 酸 素消費量安測定して，細菌の中間代謝産物が精子細胞に 
1966. 12 月

対して metabolic substance, または stimulatory agent として働きうることを観察している。これらの報告にみ られるように, ある種の細菌の存在はときに精子生存に 有效に作用する場合も㐫りうるが，一般には決して好ま しいものではないといえよう。

今回の調㭗の結果, 原精液の細菌污染度はきわめて高 いことが明らかとなったが，一般に原精液の細菌活染源 としては次の四っの経路が挙げられよう。すなわち，1) 種雄牛が特異的にブルセラ病, ビブリオ病に罹患し, 生 殖器およびその付属器官に病巣を有し, これらの病原菌 が一次的に精液内に出現する場合，2）大腸菌，コリネ バクテリア菌, ブドウ球菌などの尿路感染によって泌尿 器官に炎症があって, これらの起因菌が射精時に混入 与る場合，3）包皮腔また法尿道に付着した種々の細菌 が精液採取時に混入する場合，4）精液の採取，処理作 業中の污染ならびに使用器具の滅菌不完全, などであ る。

RUEBKE ${ }^{6)}$ 注 50 頭の雄牛生殖器の細菌検查を行ない, 細菌検出部位は包皮腔, 龟頭, 尿道下部に限局していて, その他の部分はまったく無菌であったと報告し, 田中 ら ${ }^{10)}$ も雄豚についてほぼ同様なことを認めている。わ机 われの調查および実験において，包皮腔洗浄によって精 液えの混入菌数がいらじるしく隇少すること, さらに原 精液からの検出菌種泣 Staph. aureus, Coryne. pyogenes などを除いては，ほとんどが腸管内生悽菌あるいは自然 界に広く分布している死物寄生菌の範号ゆうに入るもの で, これらの細菌が土潩, 糞便, 敷营などを介して包皮 腔内に侵入付着したものと考えられる。

したがって, 実際汇精液の細菌污染源の主役を潰じて いるものは包皮腔内の付着細菌であって, これらが採精 洔に精液内に混入するものであろう。そしてその他の污 染経路は, 通常, 量的には浮とえど無視することも可能 と考えられるので, 精液の細菌污染の防止に採精前の包 皮腔洗浄のもつ意義はきわめて大きいものがあるとい元 よう。

しかしながら，包皮腔洗浄によっても精液の污染を完 全に防除すること流もとより困難である。人工授精に使 用する希瀵精液には抗生物質の添加が行なれれている

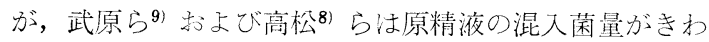
めて多い場合には，添加した抗生物質の細菌抑制效果が 不十分で, 希橎精液中に細菌が生き残りうることを述心 ている。

したがって, 希啋精液の細菌污染学防止して清浄な精
家畜繁殖誌 12 巻 3 号

液を供給するためには, 採精前の十分な包皮腔洗浄と希 釈精液への抗生物質の添加とがきわめて必要かつ適切で あると考えられる。

\section{総括}

牛の原精液 219 例の細菌污染の実態を調査して, つ ぎの結果をえた。

1. 原精液の細菌污染度は高く, その混入菌数注 $2 \times$ $10^{3}$ コ $/ \mathrm{m} l$ から $1.7 \times 10^{7}$ コ $/ \mathrm{m} l$ にわたってており, $10^{6}$ コ/ml をこえるものが $21.7 \%$ に認められた。しかし採 精前に包皮腔洗浄を行なった精液では，無洗浄採取精液 に比べて混入菌数は明らかに減少していた。

2. 原精液から検出された大部分の細菌法いわゆる非 病原菌であり，主として包皮腔内付着菌の混入によるも のであり，原精液の細菌污染防止に注採精前の包皮腔洗 浄が有効であることが実験的にもうらがきされた。

3. 包皮腔洗浄はたえに原精液の細菌污染度を減少さ せるばかりでなく, 希釈精液に添加した抗生物質の細菌 抑制効果を助長し，清浄な精液の供給に有益であること を諭じた。

終わりにご指導ならびにご校閲をいただいた山内支場 長にお礼申し上げます。

(1966. 7. 18 受付)

\section{文献}

1) Edmonson, J. E., K. L., Tallman \& H. A., Herman.: Missori Agric. Exp. Stat. Res. Bull. 444, 1949. 2) Gilman, H. L.: J. Amer. Vet. Med. Assoc. 60, 416, 1922. 3) Gunsalus, I. C., G. W., Salisbury, \& E. L., Willet, : J. Dairy Sci. 24, 911, 1941. 4)

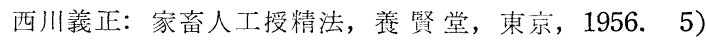
Prince, P. W., J. O., Almquist, \& J. J. Reid,; $J$. Dairy Sci. 32, 849, 1949. 6) Ruebre, H. J.: Amer. J. Vet. Res. 12, 14, 1951.7$)$ Salisbury, G. W.: Proc. Amer. Animal Prod., 32 nd Ann. Meet. 210, 1939. 8）高松(泰)・倉益(茂) ・ 今村(泰)：畜產の研 究，14，287，1959.9）武原(交)・田口(資)・長南(茂)・ 爪生(一)：神奈川衛生研年報，第 8 集，64，1959。10） 田中 (宏) -丹羽 (太) - 瑞穗(当) - 吉田 (信): 農技研報告, No. 1, 61, 1959. 11) TRUblood, M. S.: J. Dairy Sc:. 40, 149, 1957. 12) Webster, W. M.: Aust. Vet. J. 8, 199, 1932. 13) Willams, W. W.: Cornell Vet. 10, 87, 1920. 


\section{Summary}

It is very important to control bacterial contamination of bull semen not only for maintaning good fertility in artificial insemination by the semen but for preventing genital infection in the cow served by it. For this purpose sulfanilamide, penicillin and dihydrostreptomycin are customarily added to semen diluents. Since 1957 I have been studied on the prevention of bacterial contamination of bull semen.

The purpose of the work presented here was to investigate the actual condition of bacterial contamination of original bull semen. A total of 221 semen samples collected from breeding bulls were used as meterial. The results obtained were as follows;

1) Degree of the bacterial contamination of original bull semen was considerably high, the number of bacteria recovered being from $2 \times 10^{3} / \mathrm{m} l$ to $1.7 \times 10^{7} / \mathrm{m} l$. In $48(21.7 \%)$ of the 221 semen samples examined, the number of bacteria was over $10^{6} / \mathrm{m} l$ (Table 1 ).

2) The number of bacteria in semen from the bull in which preputial douche had been performed before semen collection decreased markedly as compared to that without preputial douch (Table 1 and Fig. 1). The effect of the preputial duoche for preventing bacterial contamination of semen was confirmed experimentally (Table 2).

3) From 219 original semen samples 750 strains of bacteria were recovered as shown in Table 3. Almost all of them were determined as non-pathogenic or saprophytic bacteria. It was supposed that the bacteria were derived primarily from the preputial cavity of the bull. 